\section{GDC responds to crisis}

In response to the COVID-19 pandemic, the General Dental Council (GDC) says that it will look sympathetically at the circumstances of any registrant who has a shortfall in their continuing professional development (CPD) declaration this year. The regulator has stated that nobody will be removed from the register because of a lack of access to CPD during the crisis period. For queries or concerns please email cenquiries@gdc-uk.org

Thousands of students will have been due to complete their professional training over the coming months and then to register with the GDC. Teaching and assessment are being severely disrupted, but the GDC has been working with education providers to ensure that as many students as possible can still have a smooth transition into practice. A statement has been published on the GDC website and includes relevant contact details: https://bit. ly/2QT8lqA.

Many will have seen the appeals to doctors, nurses and other healthcare professionals whose registration has lapsed to return to work, and the GDC has been asked whether similar arrangements will be made for dental professionals. As things currently stand, the only legal route back onto the register is by individual restoration: https://bit.ly/2Jn1qBR.

Almost all fitness to practise hearings have been postponed. The GDC aims to run urgent hearings remotely whenever possible. It will look to relist postponed hearings when safe and appropriate.

\title{
Project launched to 3D print ventilator parts and masks
}

Researchers at the University of East Anglia (UEA) have launched a project to $3 \mathrm{D}$ print ventilator parts, masks and other critical equipment to battle the COVID-19 virus.

UEA are working with the tech community to access $3 \mathrm{D}$ printers, as well people with the necessary skills to work at pace to design and make equipment.

They are also collaborating with healthcare providers to understand their needs, and hope to mobilise similar projects at other universities nationally and globally.

Project lead Dr Aram Saeed, from UEA's School of Pharmacy, said: 'It is absolutely vital that universities join forces with healthcare providers and businesses to find creative solutions to fight COVID-19.

'We need shortcuts to speed up the process of designing and developing key ventilator parts, and we hope to connect with other universities and expertise around the globe.

'It's still very early days for this project, but the response so far has been amazing. It is very much a steep learning curve, but we have a fantastic team of researchers and $\mathrm{PhD}$ students working on this, and we will be using our academic networks to help solve the problem.'
Professor Ben Garrod, from UEA's School of Biological Sciences and who is also involved with the effort, said: 'The work being done here at UEA and across the Norwich Research Park will help provide supplies and equipment at a local and national level, but we need help. We need help from businesses, other universities, individuals and so many others right now and already the response has been amazing. Printing off ventilator components, specialist masks and other equipment will, I'm sure, help those frontline NHS staff save lives across the country in the time ahead.'

The team are looking to collaborate with people with software skills - particularly Solidworks for CAD design, and those trained in 3D scanners and conversion of files to STIL files (printable version).

They are also looking for printers - specifically Fused Deposition Modeling (FMD), that uses thermoplastic filaments, brands Makerbot or similar, and SLA type printers which use liquid resins.

The scope of the project may move into re-purposing or reconfiguring existing ventilators, rapidly developing new ventilators and producing other medical supplies such as PEEP valves and face shields.

To find out more or if you can help with the project, visit: https://www. uea.ac.uk/about/-/ventilators.

\section{D printed parts: calling all dentists and technicians}

You may have heard that the British Government has given Dyson an order for 10,000 ventilators but whilst it is waiting for these to arrive, there is another way to deal with the current shortage.

There are lots of 3D printers sitting in dental and medical laboratories that can be used for such work. There is a national network sharing the details of the designs required and to collect and distribute the finished parts to the hospitals where they are needed.

Professor Adam Nulty, Dr Dan Shaffer and many other dentists, technicians, companies, 3D printers and designers have teamed up to provide this valuable and timely initiative.

If you would like to join in, your help will be directly saving lives and protecting front line healthcare workers from infection.
It is perfectly safe: you will be working in your own premises and be able to maintain your chosen level of production and isolation. Printable resin is supplied by Dental Directory and shipping costs are covered by the initiative's organisers. Any profits generated will go towards manufacturers of equipment in the initiative to cover costs of production and postage. All expenditure will be transparent.

Any remaining profit once the COVID-19 crisis is over will go to LovingByGiving and Bridge2aid.

Visit https://www.3dprintcovid19.com/ to register your interest in assisting the initiative.

You can also contact Celeste Barker at info@idda.org for further information. 